\title{
Polymorphonuclear Leucocyte Count in Diagnosis of Infection in the Newborn
}

\author{
S. A. HAIDER \\ Department of Paediatrics, Bolton District General Hospital, Bolton, Lancashire
}

\begin{abstract}
Haider, S. A. (1972). Archives of Disease in Childhood, 47, 394. Polymorphonuclear leucocyte count in diagnosis of infection in the newborn. Polymorphonuclear leucocyte counts were done in 200 infants at weekly intervals during the newborn period. In over $80 \%$ of the babies the count was below $7000 / \mathrm{mm}^{3}$. The count in 36 neonates with bacterial infection was found to be higher than the normal, in particular in the 18 infants with internal infection.
\end{abstract}

Polymorphonuclear leucocytosis has for a long time been accepted as useful in the diagnosis of bacterial infection in adults and older children. In the newborn, however, the count is not generally considered valuable.

In another communication (Haider, 1972), the role of serum IgM was discussed. What follows is in fact an extended report on that study. The purpose of this paper is to examine the role of polymorphonuclear leucocyte count (PLC) in the diagnosis of infection in the newborn.

In addition to the routine weekly estimation the count was also done within 24 hours of the appearance of the infection.

\section{Result}

The results are tabulated in Tables I-IV. For clinical details reference should be made to the earlier communication (Haider, 1972).

In over $80 \%$ of the normal NBW (normal birthweight, i.e. weighing over $2.5 \mathrm{~kg}$ at birth) babies, the PLC was below $7000 / \mathrm{mm}^{3}$ during the neonatal period (Table I). In normal LBW (low birthweight,

TABLE I

Weekly $P L C^{\star}$ in 100 Normal NBW Infants During Neonatal Period

\begin{tabular}{c|c|c|c|c}
\hline \multirow{2}{*}{ PLC/mm } & \multicolumn{4}{|c}{ No. of Infants } \\
\cline { 2 - 5 } & 1st Week & 2nd Week & 3rd Week & 4th Week \\
\hline Less than 7000 & 85 & 82 & 88 & 96 \\
Less than 6000 & 41 & 53 & 72 & 85 \\
\hline
\end{tabular}

$\star$ PLC $=$ Polymorphonuclear leucocyte count.

Received 15 November 1971. i.e. weighing $2.5 \mathrm{~kg}$ or less at birth) infants, the PLC in about $80 \%$ was below $6000 / \mathrm{mm}^{3}$ during the newborn period (Table II). In NBW babies

TABLE II

Weekly $P L C^{\star}$ in 100 Normal LBW Infants During Neonatal Period

\begin{tabular}{c|c|c|c|c}
\hline \multirow{2}{*}{ PLC $/ \mathrm{mm}^{3}$} & \multicolumn{3}{|c}{ No. of Infants } \\
\cline { 2 - 4 } & 1st Week & 2nd Week & 3rd Week & 4th Week \\
\hline Less than 7000 & 91 & 91 & 99 & 91 \\
Less than 6000 & 70 & 79 & 85 & 78 \\
\hline
\end{tabular}

$\star$ PLC $=$ Polymorphonuclear leucocyte count.

the count tended to fall with age but this feature was not so noticeable in LBW babies during the neonatal period.

The PLC in 15 NBW infants with infection (8 with superficial infection of skin, eyes, umbilical cord, tongue, or breast, and 7 with internal bacterial infection of gastrointestinal tract, urinary tract, or meninges) is tabulated in Table III. In all the

TABLE III

\section{$P L C^{\star}$ in $N B W$ Infants with Infection During Neonatal Period}

\begin{tabular}{ll|c|c}
\hline PLC $/ \mathrm{mm}^{3}$ & $\begin{array}{c}\text { No. of Infants } \\
\text { with Superficial } \\
\text { Infection }\end{array}$ & $\begin{array}{c}\text { No. of Infants } \\
\text { with Internal } \\
\text { Infection }\end{array}$ \\
\hline 7000 & $\begin{array}{l}\text { over } \\
\text { under }\end{array}$ & 3 & 4 \\
6000 & $\begin{array}{l}\text { over } \\
\text { under }\end{array}$ & 5 & 3 \\
\end{tabular}

$\star \mathrm{PLC}=$ Polymorphonuclear leucocyte count. 
7 infants with internal infection the PLC was over $6000 / \mathrm{mm}^{3}$. Of the $21 \mathrm{LBW}$ infants with infection (10 with superficial and 11 with internal infection) the PLC in all 11 cases with internal infection was over $6000 / \mathrm{mm}^{3}$ and in 8 of these the count was over $7000 / \mathrm{mm}^{3}$. In 9 of the 10 cases with superficial infection the PLC was over $6000 / \mathrm{mm}^{3}$.

\section{Discussion}

Xanthou (1970) has reviewed the literature and has established the leucocytic blood picture in normal term and premature infants during the newborn period. After the first 3 days of life PLC exceeding $7000 / \mathrm{mm}^{3}$ was not found in her cases. She (Xanthou, 1968) has further shown that in newborn babies suffering from infective illness the absolute values of polymorphonuclear leucocyte were generally higher than in the normal babies. In such cases PLC of over $7000 / \mathrm{mm}^{3}$ as well as significant daily differences in the count were often found after 3 days of life.

This study differs from hers in some respects. The number of cases was significantly greater than in her study. The counts, however, were done at more frequent intervals and in more detail by her. Something may also be said about the standard of the count and percentage error. The purpose of this study was to assess the clinical value of the PLC which could be generally available in all the hospitals, especially the less privileged ones.

The findings in the normal neonates (NBW and LBW) are fairly well in agreement with Xanthou's (1970)-the PLC in well over $80 \%$ is below $7000 /$ $\mathrm{mm}^{3}$. It may be observed (Tables III and IV) that in none of the $7 \mathrm{NBW}$ and $11 \mathrm{LBW}$ infants with internal bacterial infection was the PLC less than $6000 / \mathrm{mm}^{3}$, and in general the results of this study on the neonates with infection do not significantly differ from that of Xanthou's (1968). On detailed analysis, however, the PLC in the NBW newborns with superficial infection is not significantly different from the normal (Fisher's exact test-at $7000 \mathrm{P}=0.37$ and at $6000 \mathrm{P}=0.25$ ), but in those NBW infants who had internal infection the PLC is significantly higher than the normal
TABLE IV

$P L C^{\star}$ in $L B W$ Infants with Infection During Neonatal Period

\begin{tabular}{ll|c|c}
\hline PLC $/ \mathrm{mm}^{3}$ & $\begin{array}{c}\text { No. of Infants } \\
\text { with Superficial } \\
\text { Infection }\end{array}$ & $\begin{array}{c}\text { No. of Infants } \\
\text { with Internal } \\
\text { Infection }\end{array}$ \\
\hline 7000 & over & 3 & 8 \\
6000 & under & 7 & 3 \\
& over & 9 & 11 \\
\end{tabular}

^Polymorphonuclear leucocyte count.

(at $7000 \mathrm{P}=0.018$ and at $6000 \mathrm{P}=0.00052$ ). In LBW babies with superficial infection the proportion with PLC higher than $7000 / \mathrm{mm}^{3}$ does not significantly exceed that in the controls ( $P$ $=0 \cdot 16$ ), but there is a significantly higher proportion with PLC above $6000(\mathrm{P}=0 \cdot 000050)$. The PLC in LBW infants with internal infection is significantly higher than normal (at $7000 \mathrm{P}=$ 0.0000000064 and at $6000 \mathrm{P}=0.000000016$ ). In conclusion it appears that PLC may be helpful in the diagnosis of infection in the newborn, in particular the negative value of the count is quite significant-in none of the 18 newborn infants with internal bacterial infection was the PLC below $6000 / \mathrm{mm}^{3}$.

I thank Dr. W. Dickson for encouragement and advice; Mr. A. C. C. Gibbs, Department of Social and Preventive Medicine, University of Manchester, for help with statistics; Sister Stafford, Sister Grimshaw; and the staff of the Pathology Department.

REFERENCES

Haider, S A. (1972). Serum IgM in diagnosis of infection in the newborn. Archives of Disease in Childhood, 47, 382.

Xanthou, M. (1968). Leucocyte counts on healthy and ill babies during the neontal period. M.D. Thesis. Medical School, University of Athens.

Xanthou, M. (1970). Leucocyte blood picture in healthy full-term and premature babies during neonatal period. Archives of Disease in Childhood, 45, 242.

Correspondence to Dr. S. A. Haider, Ministry of Health, P.O. Box No. 393, Muscat, Oman. 